Department of Education, under Title VI of the Higher Education Act. Applicants must be U.S. citizens or permanent residents. Application forms are available from the African Studies Center. The initial deadline is February 19, 1999, however, fellowships can be awarded any time after this date. Applications will be considered until March 27,1999 , although all fellowships may have been awarded by that date.

\section{PAPER CALENDAR}

\section{March 1, 1999-African Child Conference} - The African Studies Program, Ohio University, announces a call for papers for the Institute for the African Child Inaugural Conference to be held on June 16-19, 1999. The theme of the conference is, "The Children of Africa: Resources for Learning, Health and Society." There will also be a special workshop on Saturday, June 19, on methods for incorporating knowledge about Africa's children across K12 curriculum. Proposals may be for individual or panel presentation. The proposals should include the title page, author names, affiliations, telephone, fax and email addresses. The length of the abstracts should not exceed two pages. The deadline for submission is March 1, 1999. For further information contact: Polly Sandenburgh, African Studies Program, Ohio University, Burson House, 56 E. Union Street, Athens, $\mathrm{OH}$ 45701, Email: sandenbu@ohiou.edu

May1, 1999-Africa and the Democratic Wave

$\checkmark$ Submissions for the fifth annual Mid-America Alliance for African Studies conference, with co-sponsorship by the African Studies Resource Center of the University of Kansas, with the theme of "Africa and the democratic wave : evaluating a decade of transformations in politics, economy, the arts, and society," are due by May 1, 1999. Conference takes place Sept. 24-25, 1999. Keynote speaker will be Ngugi wa Thiong'o, noted Kenyan author and activist on behalf of the freedom of the writer in national society. Proposals are to consist of no more than a one-page abstract and title and should be submitted to: Garth Myers, Geography Department, Lindley Hall, University of Kansas, Lawrence, KS 66045. Tel. 785-864-4291, fax 785-864-5378, e-mail gmyers@ukans.edu. For further information on the keynote speaker, panel sessions, conference theme, and online registration form, check the conference web siteat:http://www.ukans.edu/ asrc/Maaas -1.htm

June 30, 1999 - African Identity

$\checkmark$ The Department of Art History and Ar- chaeology, University of Maryland, College Park, invites abstracts for papers to be presented at the symposium "Whither Bantu Studies: Investigations of an African Identity." The symposium will be held in October 1999. The purpose of the interdisciplinary symposium is to reexamine the current understanding of Bantu peoples and to promote new ideas for future studies. Professionals and graduate students working in the fields of anthropology, archaeology, history, art history, and linguistics are welcome to submit abstracts of 20 minute presentations by June 30, 1999. For more information contact: Ekpo Eyo, Department of Art History and Archaeology, University of Maryland, College Park, Art/Sociology Building, College Park, MD 20742; Telephone: 301-314-1485; Fax::

301-314-9652.

Eastern African Social Science Research Review

-The Eastern African Social Science Research Review (EASSRR) calls for papers for its biannual publication of the Organization for Social Science Research in Eastern and Southern Africa (OSSREA). The focus of the articles should be the economic, social and political problems of the region and relevant contributions dealing with other subregions of Africa as well as broader issues concerning the continent. Book reviews, notes and comments are also accepted for publication. Manuscripts may be sent to: The Editor, Eastern African Social Science Research Review, OSSREA, PO Box 31971, Addis Ababa, Ethiopia.

\section{MEETING CALENDAR}

March 10-13, 1999 - African Literature Association

$\Delta$ The African Literature Association will hold its 25th annual meeting on March 10-13, 1999 in Fes, Morocco. The conference theme is: Continental NorthSouth and Diaspora Connection and Linkages. For more information contact: Edris Makward, ALA 1999 Coconvener, 1414 Van Hise Hall,1220 Linden Drive, Madison, WI 53706, Telephone: (608) 262-2487, Telephone: (608) 262-2487, Fax: (608) 265-4151, Email: emakward@facstaff.wisc.edu.

April 15-17, 1999 - African Women Global Network

$\Delta$ The African Women Global Network, together with the Center for African Studies and Ohio State University, will host the second annual international conference on women on April 15-17, 1999, in Columbus, Ohio. The theme of the conference is: "Technology, Art and Culture". For more information write to: The Ohio State
University,

AWOGNet at AWOGNet, Center for African Studies, Ohio State University, 314 Oxley Hall, 1712 Neil Avenue, Columbus, $\mathrm{OH}$ 43210-1219; Telephone: (614) 292-3238.

June 16-19, 1999 - Institute for the African Child

$\Delta$ The African Studies Program, Ohio University, announces the Institute for the African Child Inaugural Conference to be held on June 16 - 19, 1999. The theme of the conference is, "The Children of Africa: Resources for Learning, Health and Society." There will also be a special workshop on Saturday, June 19, on methods for incorporating knowledge about Africa's children across K12 curriculum. For further information contact: Polly Sandenburgh, African Studies Program, Ohio University, Burson House, 56 E. Union Street, Athens, $\mathrm{OH}$ 45701, Email: sandenbu@ohiou.edu

\section{October 1999 - Bantu Studies}

$\Delta$ The Department of Art History and Archaeology, University of Maryland, College Park, announces the symposium "Whither Bantu Studies: Investigations of an African Identity," to be held in October 1999. The purpose of the interdisciplinary symposium is to reexamine the current understanding of Bantu peoples and to promote new ideas for future studies. For more information contact: Ekpo Eyo, Department of Art History and Archaeology, University of Maryland, College Park, Art/Sociology Building, College Park, MD 20742; Telephone: 301-314-1485; Fax: 301-314-9652.

\section{EMPLOYMENT OPPORTUNITIES}

\section{Director of Administration, The Africa Fund} * The Africa Fund seeks an organized individual to supervise finances and administration of a 610 person staff and assist in developing program plans and strategic goals for a 32 year old nonprofit agency working for equitable U.S.Africa policy. Experience analyzing and summarizing financial reports is essential. Candidate must also demonstrate the ability to prioritize, liaise with accountants, lawyers, staff and Board, oversee budget preparation, prepare appropriate government and donor reports, maintain personnel records, and coordinate development proposals. Writing and people skills are important. The Africa Fund is an equal opportunity employer; salary high 30 s. For full job description see the web page www.prairienet.org/acas/afund.html or write: Personnel Committee, The Africa Fund, 50 Broad Street, Suite 711, New York, NY 10004. Application deadline: Position open until filled. 